\title{
Temporal variations in volumetric magma eruption rates of Quaternary volcanoes in Japan
}

\author{
Takahiro Yamamoto*, Takashi Kudo and Osamu Isizuka
}

\begin{abstract}
Long-term evaluations of hazard and risk related to volcanoes rely on extrapolations from volcano histories, including the uniformity of their eruption rates. We calculated volumetric magma eruption rates, compiled from quantitative eruption histories of 29 Japanese Quaternary volcanoes, and analyzed them with respect to durations spanning $10^{1}-10^{5}$ years. Calculated eruption rates vary greatly $\left(10^{1}-10^{-4} \mathrm{~km}^{3}\right.$ dense-rock equivalent/1000 years) between individual volcanoes. Although large basaltic stratovolcanoes tend to have high eruption rates and relatively constant repose intervals, these cases are not representative of the various types of volcanoes in Japan. At many Japanese volcanoes, eruption rates are not constant through time, but increase, decrease, or fluctuate. Therefore, it is important to predict whether eruption rates will increase or decrease for long-term risk assessment. Several temporal co-variations of eruption rate and magmatic evolution suggest that there are connections between them. In some cases, magma supply rates increased in response to changing magma-generation processes. On the other hand, stable plumbing systems without marked changes in magma composition show decreasing eruption rates through time.
\end{abstract}

Keywords: Eruption rate, Magma-discharge step diagram, Quaternary volcano, Japan

\section{Introduction}

Quantitative evaluation of eruptive histories is key to our understanding of volcanism and attempts to predict volcanic activity. Especially important are rates of magma generation and eruption, which are key factors affecting the petrological and geochemical evolution of magma bodies and eruptive styles due to the intrinsic coupling between magma recharge, fractional crystallization, melting of crustal rocks, and volatile saturation in the melt (Spera et al. 1982; Shaw 1985; Annen et al. 2006). Although global compilations of time-averaged volumetric eruption rates reveal long-term patterns of magmatism and volcanism (Crisp 1984; Wadge 1984; White et al. 2006), eruption rates at individual volcanoes vary widely. Some active volcanoes erupt repeatedly at intervals of $10^{1}-10^{3}$ years, such that the cumulative erupted volume increases linearly with time (Nakamura 1964;

\footnotetext{
*Correspondence: t-yamamoto@aist.go.jp

Geological Survey of Japan, AIST, Higashi 1-1-1 Central 7, Tsukuba 305-5867, Japan
}

Wadge 1982; King 1989). However, most composite volcanoes are characterized by brief periods of intense activity followed by repose periods that span significant portions of their lifetimes (Davidson and de Silva 2000; Hora et al. 2007; Klemetti and Grunder 2007).

External hazards (including volcanic eruptions) and their associated risks are increasingly recognized as important for nuclear power plant safety. After the 2011 Fukushima Daiichi Nuclear Power Plant accident, the Nuclear Regulation Authority of Japan revised its regulatory requirements and developed the Evaluation Guide for Volcanic Hazards in 2013. This guide requires the evaluation of volcanic risks over several decades, corresponding to the typical operational period of nuclear power plants. It is possible to extrapolate from the quantitative eruption histories of nearby volcanoes, based on geological records, and forecast likely volcanic events. However, the guide provides no explicit criteria for extrapolation. Additionally, our knowledge of complex volcanic processes is insufficient for long-term eruption forecasting at individual volcanoes. Therefore, we must 
accumulate quantitative eruption histories, analyze their patterns, and set criteria for evaluation of volcanic hazards likely to affect nuclear power plants.

According to the Nuclear Regulation Authority guide, an application for the Sendai nuclear power plant by the electric company showed a cyclic recurrence of calderaforming eruptions since $0.6 \mathrm{Ma}$, using a compound diagram of cumulative eruption volumes versus time for some caldera volcanoes of southern Kyushu Island. However, Koyama (2015) claimed that the evaluation method is arbitrary, because the eruption cycles cannot be extrapolated uniformly across the different volcanoes. Similar diagrams since $2 \mathrm{Ma}$ for Yellowstone caldera (Christiansen 1984) and the Taupo Volcanic Zone (Houghton et al. 1995) did not demonstrate such cyclicity for those caldera-forming eruptions, whereas flare-ups of caldera-forming eruptions have occurred at intervals of several million years in other volcanic fields (Salisbury et al. 2011; Yamamoto 2011). Eruption rates averaged over a volcano's lifetime (Crisp 1984; Tomiya 1991; White et al. 2006) do not necessarily permit the forecasting of volcanic activity by simple extrapolation of these mean values. It is important to better understand the evolution of eruption rates through time and their controlling factors.

\section{Eruption rates of Quaternary volcanoes}

Yamamoto (2015) compiled quantitative eruption histories of 56 major Japanese volcanoes over the last several hundred thousand years, plotting cumulative eruption volume versus time (magma-discharge step diagram; Koyama and Yoshida 1994); dense-rock equivalent (DRE) volumes were calculated from erupted volumes, and eruptive ages were recalibrated to calendar dates. Furthermore, Yamamoto (2015) analyzed and reported data quality and dataset reliability. In this study, we calculated volumetric magma eruption rates using 29 well-documented examples (Fig. 1) from Yamamoto (2015). Except for the Izu-Tobu monogenetic volcanoes, the others are composite volcanoes from basalt to rhyolite in composition; some volcanoes include caldera-forming events.

For long-term evaluation, it is necessary to examine the uniformity of eruption rates, as that is the premise of extrapolation based on eruption histories. Thus, we compared eruption rates at different time scales. Because uncertainties in eruption ages and volumes increase with age of the eruptive products, it is difficult to compare the eruption rates of poorly preserved, older eruptions to recent eruptions occurring over a similar time interval. Therefore, we defined the duration as the time when it dated back to from last eruption event, and plotted it on a logarithmic scale to indicate average magma eruption rates as a function of the duration spanning $10^{1}-10^{5}$ years
(Fig. 2). The maximum durations of the volcanoes are almost equivalent to their lifetimes, such that their average eruption rates are nearly the same values estimated by Tomiya (1991). On the other hand, the minimum durations of the volcanoes include at least two recent magmatic eruption events. Thus, there is a tendency for volcanoes characterized by short minimum durations to show high eruption rates, and those with the long minimum durations to show low eruption rates.

Calculated magma eruption rates show various patterns, and they differ widely between volcanoes and durations. The eruption rate of Sakurajima, the most active volcano in Japan, is $1-10 \mathrm{~km}^{3}$ DRE/1000 years, a typical value for long-term eruptions of basaltic to andesitic volcanoes in the world (White et al. 2006). On the other hand, at certain durations its eruption rates are as small as $10^{-4} \mathrm{~km}^{3} \mathrm{DRE} / 1000$ years. In terms of temporal variations, Fuji, Izu-Oshima, and Miyake, all large basaltic stratovolcanoes of the Izu-Mariana-Bonin arc, are characterized by high eruption rates that do not strongly depend on durations. At other volcanoes, eruption rates are not constant at different durations, with rates, rising, dropping, or repeating both by at least an order of magnitude. Although Nakamura (1964) showed that constant eruption rates are typical at Izu-Oshima volcano, this is an uncommon case in Japanese arcs. Such changes of eruption rates are important for the evaluation of future volcanic activity, because it is necessary to forecast the change in eruption rate. In other words, the likelihood that the eruption rate will increase or decrease in the future must be reflected in the long-term evaluation.

\section{Relationship between eruption rate and magmatic evolution}

In general, magma composition changes with volcano growth, as does eruption rate. It is therefore necessary to understand how magmatic processes differ during increasing and decreasing rates of eruption. We present several well-documented examples of temporal changes in magma composition for cases of both decreasing and increasing eruption rate.

\section{Increasing case 1: Sakurajima Volcano}

Sakurajima (Fig. 1) is a post-caldera composite volcano of Aira caldera, formed by the $30 \mathrm{ka}$ catastrophic Ito pyroclastic flow eruption (Aramaki 1984). Sakurajima average eruption rates increased dramatically at repose intervals of 100-10,000 years (Fig. 2). Eruptive products are medium- $\mathrm{K}$ andesite to dacite and consist of the Older and Younger Kitadake and Older and Younger Minamidake stages. The Older and Younger Kitadake stages are separated by a quiescence of about 11,000 years (Kobayashi et al. 2013). The dipping pattern of the eruption 


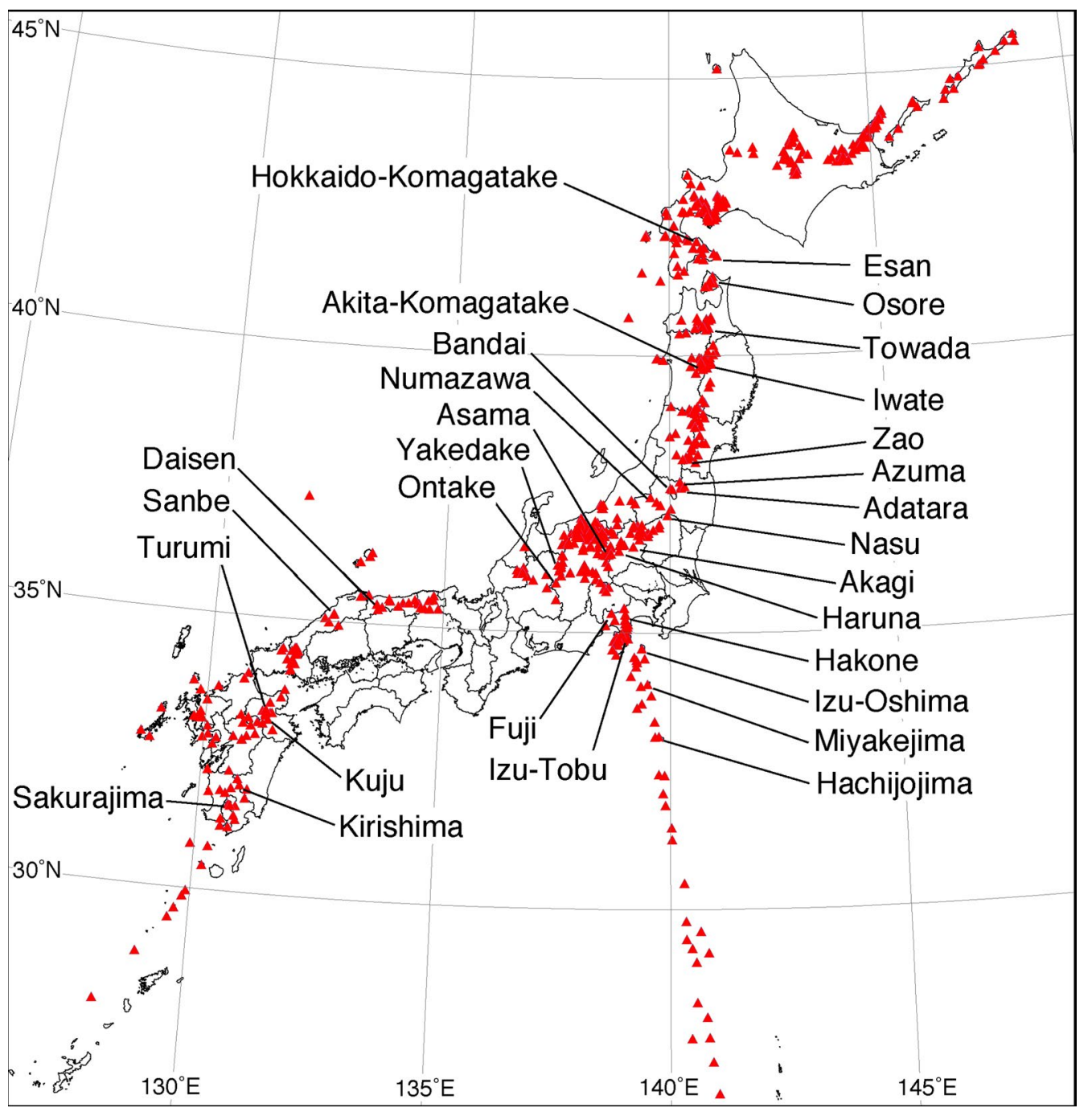

Fig. 1 Index map of 29 volcanoes calculated volumetric eruption rates. Red triangles are Quaternary volcanoes in Japan

rate around 10,000 years in duration (Fig. 2) is corresponding to this quiescence. After the largest eruption (P14) occurred at $12.8 \mathrm{ka}$ (the beginning of the Younger Kitadake stage), the cumulative eruption volume rapidly increased during the Older and Younger Minamidake stages (Fig. 3). During each eruptive stage, the chemical composition of the eruptive products has changed (Uto et al. 2005; Takahashi et al. 2011, 2013). For example, Zr/ Th ratios have increased since about $4.5 \mathrm{ka}$, and ${ }^{87} \mathrm{Sr} /{ }^{86} \mathrm{Sr}$ ratios have decreased gradually since the Ito eruption (Fig. 4; Uto et al. 2005). These trends, and high Zr/Th and low ${ }^{87} \mathrm{Sr} /{ }^{86} \mathrm{Sr}$ in mafic inclusions, suggest mafic magma recharge to the Aira caldera magma chamber and mixing with crustal-derived felsic magma. The marked increase in eruption rate and the change of magmatic compositions have simultaneously occurred during the present
Younger Minamidake stage (Figs. 3, 4). This relationship may present that the supply of mafic magma from the mantle has increased with time.

\section{Increasing case 2: Numazawa Volcano}

Numazawa (Fig. 1) is a small caldera volcano in the Northeast Japan back-arc. Eruptions at Numazawa began at $110 \mathrm{ka}$, and increased in eruption rate until the caldera-forming eruption at $4.6 \mathrm{ka}$ (Fig. 5; Yamamoto 2003). Eruptive products decrease in $\mathrm{SiO}_{2}$ content from rhyolite to dacite and show homogeneous $\mathrm{Sr}$ isotopic ratios (Fig. 6). Based on trace-element abundances, this trend is plausibly caused by increasing degrees of batch partial melting at a constant bulk distribution coefficient (Yamamoto 2011). Thus, the compositional variation through time indicates that the increase in eruption rate directly 


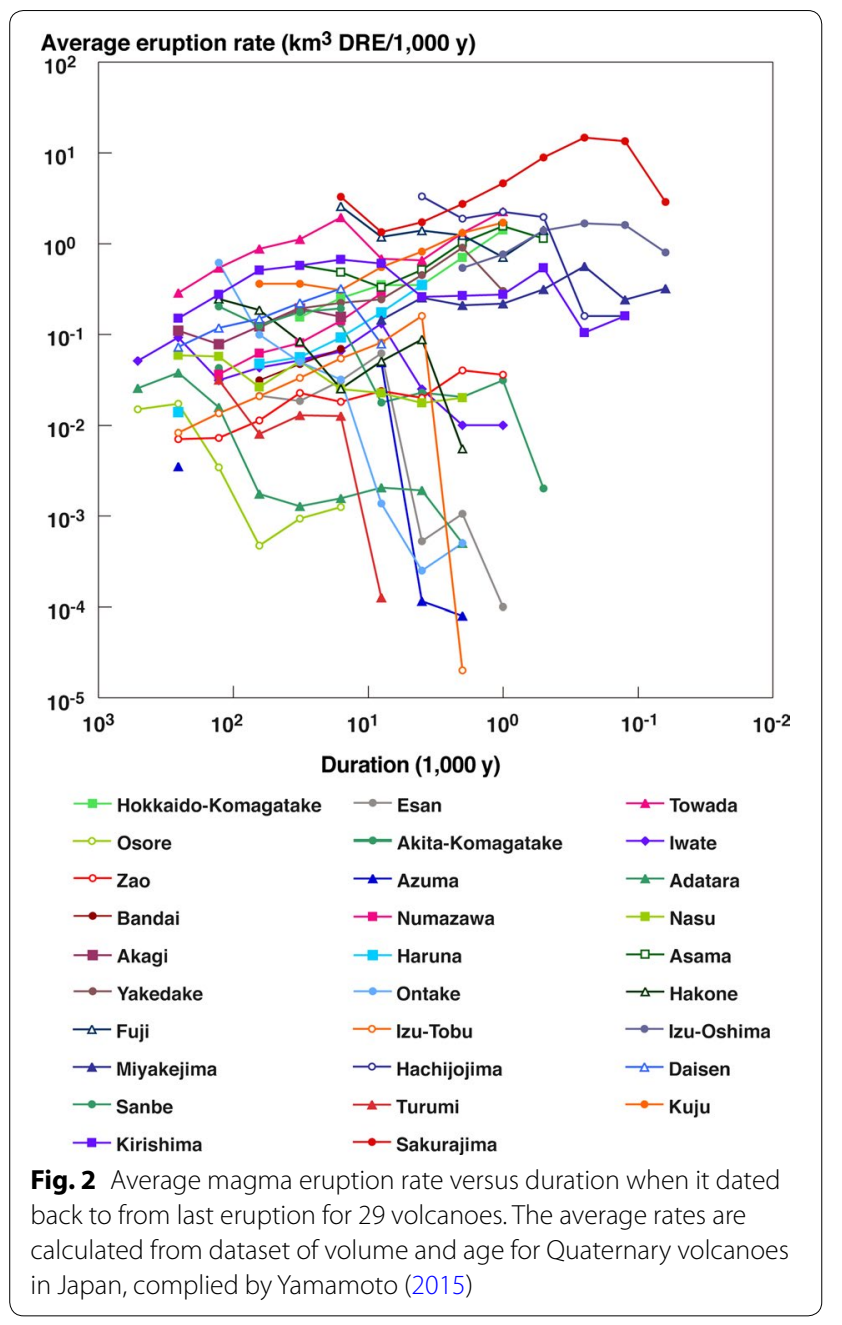

reflects the magma production rate. Furthermore, increasingly depletion of middle and heavy rare earth elements (REEs) with time suggest progressive amphibole fractionation during partial melting of lower-crustal materials (Fig. 7); it is thus likely that repeated intrusions of mantle-derived melts have gradually increased the temperature of the cooled lower crust since $110 \mathrm{ka}$.

\section{Increasing case 3: Akagi Volcano}

Akagi is a large composite volcano in the volcanic front of the Northeast Japan arc (Fig. 1). The eruptive history of Akagi comprises the volcanic cone-building stage (ca. $220-150 \mathrm{ka}$ ) that erupted voluminous low- to medium-K basaltic andesite to andesite lava flows, the pumice-eruption stage (ca. 150-44 ka) that produced many medium$\mathrm{K}$ andesite to dacite pumice falls and pumice flows, and the post-caldera stage (44-30 ka) that effused medium-K rhyolite lava domes (Moriya 1970; Takahashi et al. 2012). After the volcanic cone-building stage at a high magmadischarge rate, the eruption rate declined until the

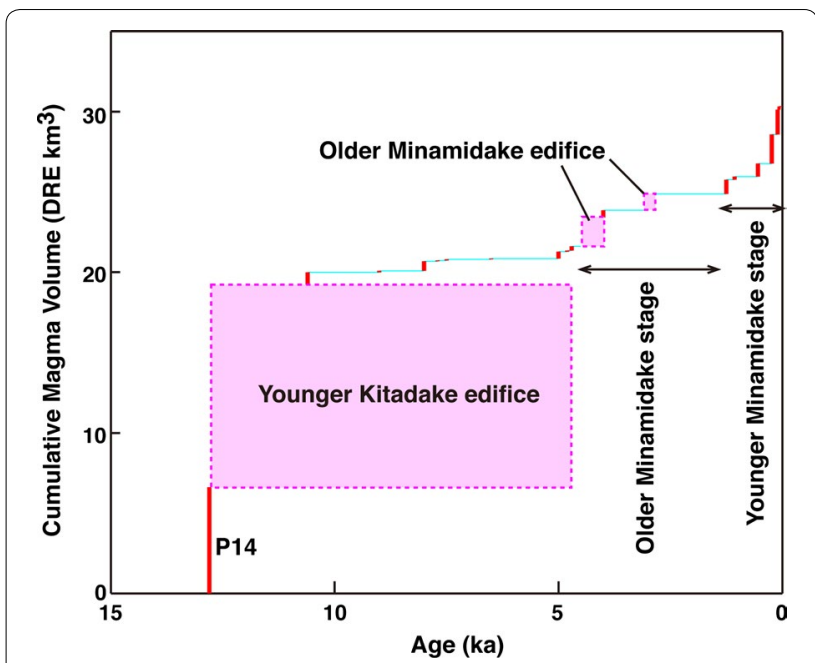

Fig. 3 Cumulative magma volume erupted from Sakurajima Volcano. A red solid line represents an eruption event. A pink square shows the ranges of volume and age for a volcanic edifice which is undivided into separate eruption events. P14 is the Sakurajima-Satsuma tephra, which occurred at the beginning of Younger Kitadake stage after a long repose (Kobayashi et al. 2013). The eruption rate is apparently increasing in the recent Younger Minamidake stage

vigorous pumice-eruption sub-stage (P3 in Fig. 8; Yamamoto 2016). Trace-element abundances and $\mathrm{Sr}-\mathrm{Nd}-\mathrm{Pb}$ isotopes suggest that Akagi magmatism is characterized by interactions between mantle-derived magma and lower-crustal materials (with amphibole fractionation; Kobayashi and Nakamura 2001). Felsic magmas erupted during the pumice-eruption stage are more depleted in middle to heavy REEs than magmas erupted during the cone-building stage, suggesting amphibole fractionation and/or a greater crustal melt contribution during the pumice-eruption stage (Fig. 9). Decreases in the K contents of magmas erupted at the beginning of sub-stages P1, P2, and P3 indicate the repeated injection of voluminous mantle-derived magma into the lower crust (Fig. 10, Yamamoto 2016) and correspond to increased eruption rates (Fig. 8). Post-caldera lava domes, the most recent eruptive products of Akagi, are the most felsic but the most isotopically depleted (Kobayashi and Nakamura 2001), suggesting that production of mantle-derived magmas decreased, and they no longer interacted with crustal materials.

\section{Increasing case 4: Towada Volcano}

Towada is an active caldera volcano in the northern part of the Northeast Japan arc. Eruptive products are low-K basaltic andesite, andesite, dacite, and rhyolite (Hunter and Blake 1995). Hunter and Blake (1995) attributed the compositional evolution of Towada magmas to combined assimilation and fractional crystallization. The eruptive 


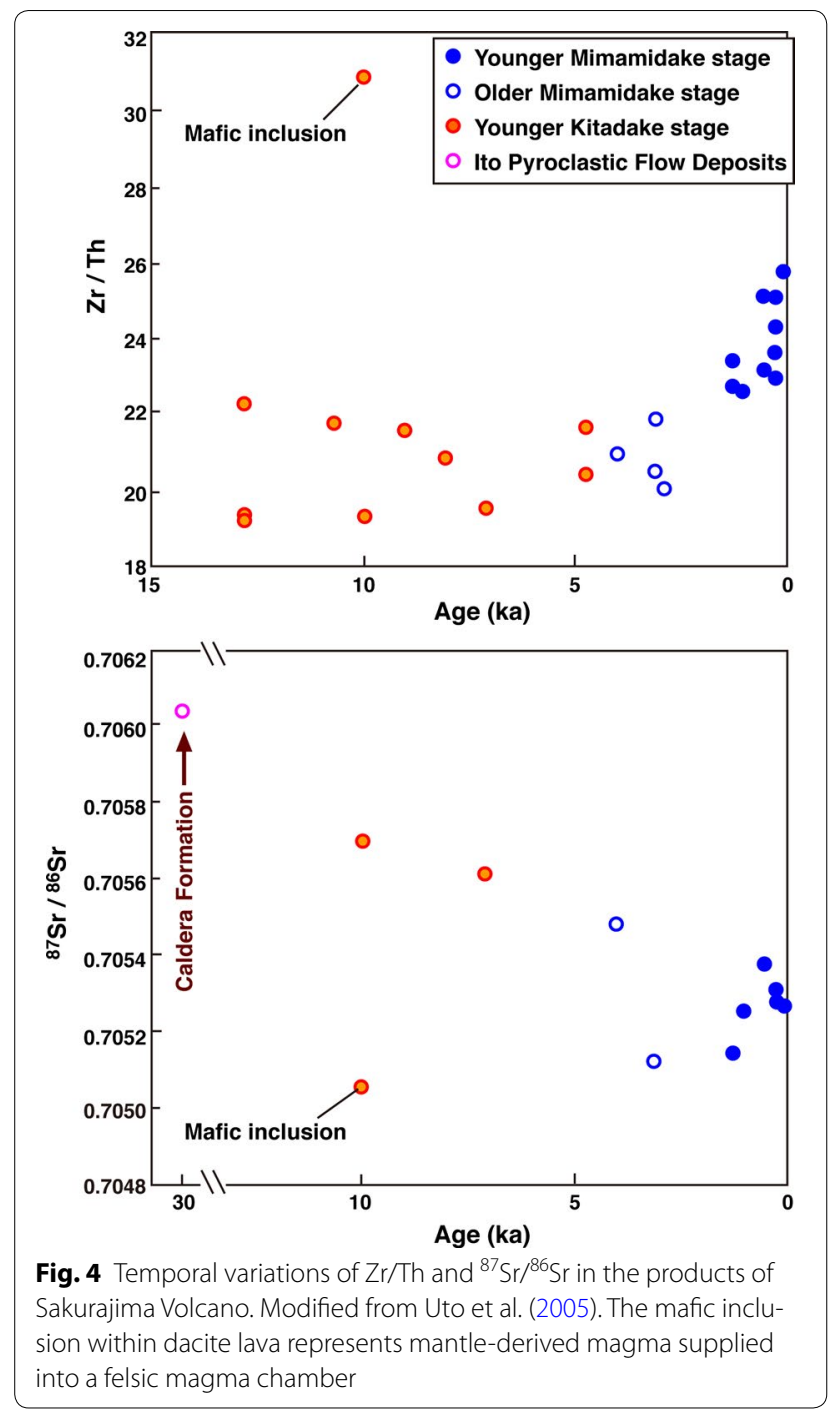

history of Towada is divided into pre-, syn-, and postcaldera stages (Hayakawa 1985); the large caldera-forming eruptions occurred during Episodes N (36 ka) and L (15.5 ka), which emplaced the Ofudo and Hachinohe Ignimbrites, respectively. Magma eruption rates increased during the syn-caldera stage (Fig. 11), associated with compositional changes of the eruptive products; $\mathrm{Zr} / \mathrm{Th}$ decreased and ${ }^{87} \mathrm{Sr} /{ }^{86} \mathrm{Sr}$ increased from the pre- to syncaldera stages (Fig. 12). We note that these compositional changes preceded the caldera-forming Episode $\mathrm{N}$ by tens of thousands of years. $\mathrm{Zr} / \mathrm{Th}$ increased and ${ }^{87} \mathrm{Sr} /{ }^{86} \mathrm{Sr}$ decreased temporarily at the onset of post-caldera volcanism, recording transient eruptions of basaltic andesite and andesite magmas that experienced less crustal assimilation (Hunter and Blake, 1995). The caldera-forming felsic magmas are more depleted in middle and heavy REEs than pre-caldera felsic magmas, similar to the cases of

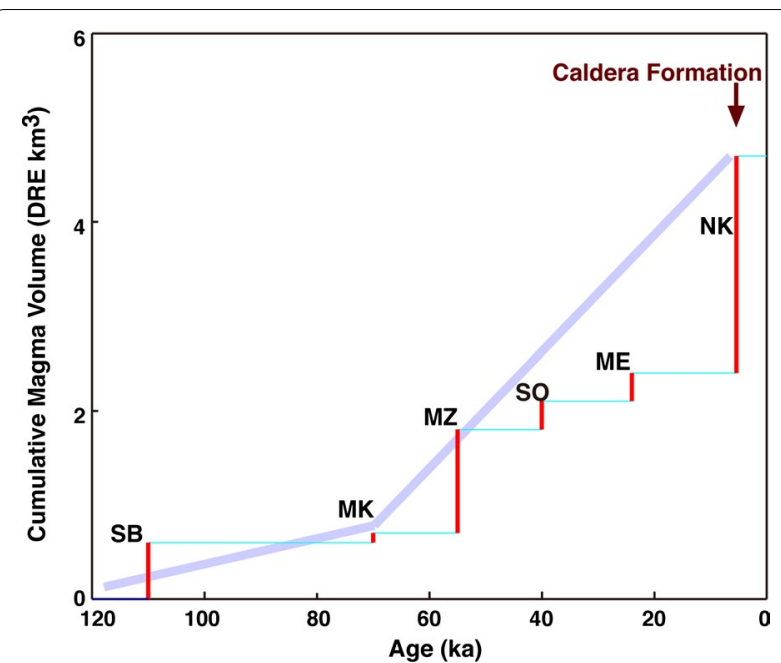

Fig. 5 Cumulative magma volume erupted from Numazawa Volcano. A red solid line represents an eruption event. A lilac solid line shows a tendency of the eruption rate. $\mathrm{SB}=$ Shibahara pyroclastic deposit; $\mathrm{MK}=$ Mukuresawa lava dome; $\mathrm{MZ}=$ Mizunuma pyroclastic deposit; $\mathrm{SO}=$ Sozan lava dome; $\mathrm{ME}=$ Maeyama lava dome; NK = Numazawako pyroclastic deposit (Yamamoto 2003)

Numazawa and Akagi volcanoes (Fig. 13). The increased eruption rate of Towada is also linked to crustal assimilation and fractional crystallization crystallization relating to amphibole.

\section{Decreasing case 1: Nasu-Chausudake Volcano}

Chausudake, the youngest edifice of the Nasu Volcano group, is on the volcanic front of the NE Japan arc (Fig. 1). Six magmatic units (CH1-6) of medium-K andesite have been emplaced as Vulcanian fallouts, block-and-ash flows, and lava flows: $\mathrm{CH} 1$ (19 ka) is the first and largest unit, and subsequent units decrease in volume (Fig. 14; Yamamoto 1997). Whole-rock compositions of CH1-6 increase linearly in $\mathrm{SiO}_{2}$ content from 56.1 to $61.2 \mathrm{wt} \%$, suggesting that the rocks derive from mixing between mafic and felsic end members; the mixing lines appear to be fixed throughout the entire eruptive history of Chausudake (Ban and Yamamoto 2002). The ${ }^{87} \mathrm{Sr} /{ }^{86} \mathrm{Sr}$ and $\mathrm{Zr} / \mathrm{Th}$ ratios of the felsic rocks are constant in all units (Fig. 15), suggesting that the felsic end-member magma was produced through melting of lower-crustal materials at the time of formation of the magma-plumbing system. The mafic end-member magmas, represented by mafic inclusions of constant composition since $19 \mathrm{ka}$, might have repeatedly ascended from a large, homogeneous lower-crustal magma chamber (Ban and Yamamoto 2002). To summarize, no major change has occurred in the magma-plumbing system since eruptions began (unit $\mathrm{CH} 1$ ); the decreasing eruption rate at Chausudake may be a result of this stable system. 


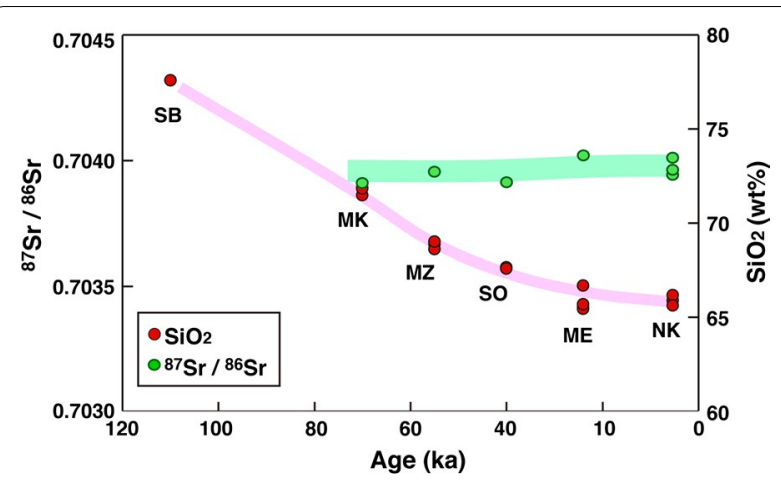

Fig. 6 Temporal variations of $\mathrm{SiO}_{2}$ (red) and ${ }^{87} \mathrm{Sr} /{ }^{86} \mathrm{Sr}$ (green) in the products of Numazawa Volcano. Abbreviations are same in Fig. 5. Although the $\mathrm{SiO}_{2}$ contents decreased with time, the isotopic ratio of Sr was constant. Data are from Yamamoto (2007)

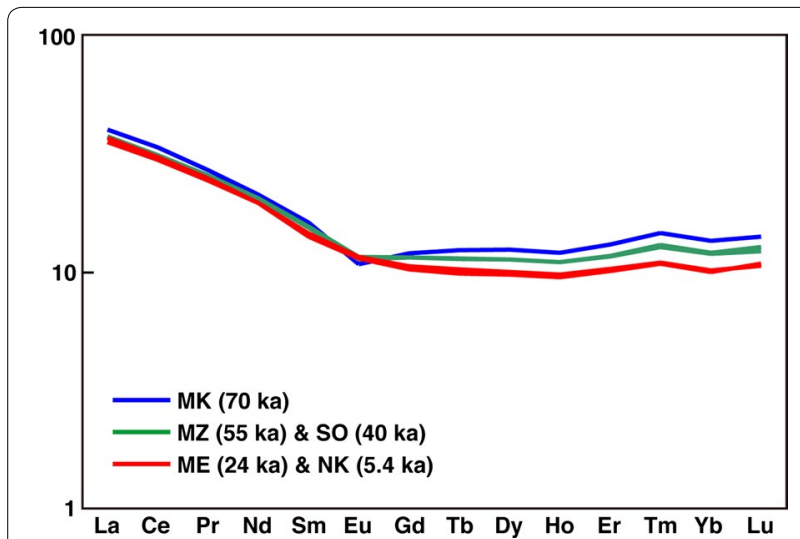

Fig. 7 Condrite-normalized REE patterns for the products of Numazawa Volcano. Abbreviations are same in Fig. 5. The normalizing values are from McDonough and Sun (1995). Middle and heavy REE in the products depleted with time. Data are from Yamamoto (2007)

\section{Decreasing case 2: Azuma-Jododaira Volcano}

Jododaira is the youngest volcano of the Azuma Volcano group, on the volcanic front of the Northeast Japan arc (Fig. 1). Since eruptions began at $7.6 \mathrm{ka}$, Jododaira has produced five magmatic units comprising Vulcanian fallouts and lava flows (Fig. 16; Yamamoto 2005). The largest volume eruption was of the Kofuji unit between 6.8 and $5.5 \mathrm{ka}$, which produced a large pyroclastic cone (Azuma-Kofuji) and many associated lava flows; more than $95 \%$ of the total $0.4 \mathrm{~km}^{3}$ DRE was erupted during this period. After the climactic Kofuji eruption, the eruption rate decreased greatly. Jododaira magmas are mainly medium- $\mathrm{K}$ andesites $\left(56.8-61.5 \mathrm{wt} \% \mathrm{SiO}_{2}\right)$, with some minor medium- $\mathrm{K}$ dacites $\left(62.7-66.6 \mathrm{wt} \% \mathrm{SiO}_{2}\right.$; Yamamoto 2005). Whole-rock compositions and ${ }^{87} \mathrm{Sr} /{ }^{86} \mathrm{Sr}$ ratios of andesite magmas of all units show a linear trend

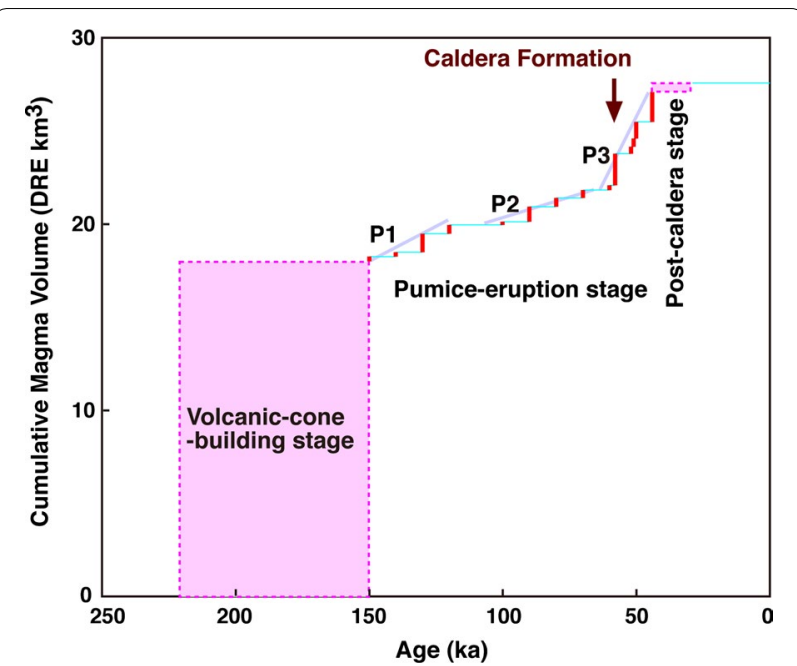

Fig. 8 Cumulative magma volume erupted from Akagi Volcano. A red solid line represents an eruption event. A lilac line shows a tendency of the eruption rate. A pink square shows the ranges of volume and age for a volcanic edifice which is undivided into separate eruption events. P1, P2 and P3 are sub-stages in the pumice-eruption stage (Yamamoto 2016)

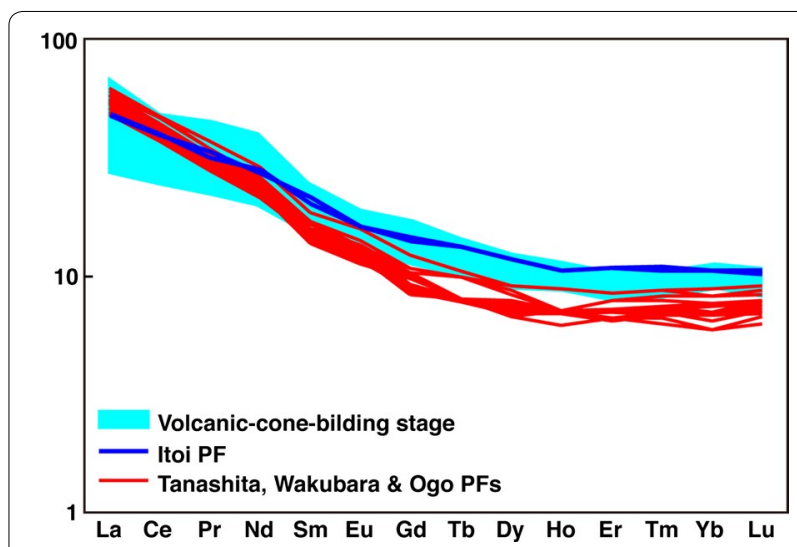

Fig. 9 Chondrite-normalized REE patterns for whole rocks of Akagi Volcano. The normalized values are from McDonough and Sun (1995). The hatched area shows the range of REE patterns for andesite lava flows in the volcanic cone-building stage (Kobayashi and Nakamura 2001). Other data are from Yamamoto (2016). The Itoi Pumice Flow $\left(\mathrm{SiO}_{2}=62.7-65.6 \mathrm{wt} \%\right)$ erupted at the end of the volcanic conebuilding stage (160 ka). The Tanashita, Wakubara, Ogo Pumice Flows $\left(\mathrm{SiO}_{2}=56.9-64.4 \mathrm{wt} \%\right)$ erupted during the pumice-eruption stage

in variation diagrams, suggesting that magmas derive from repeated mixing of the same mafic and felsic end members; dacitic magmas, however, are varied (Fig. 17). Overall, erupted magma compositions do not change drastically over the lifetime of the volcano. 


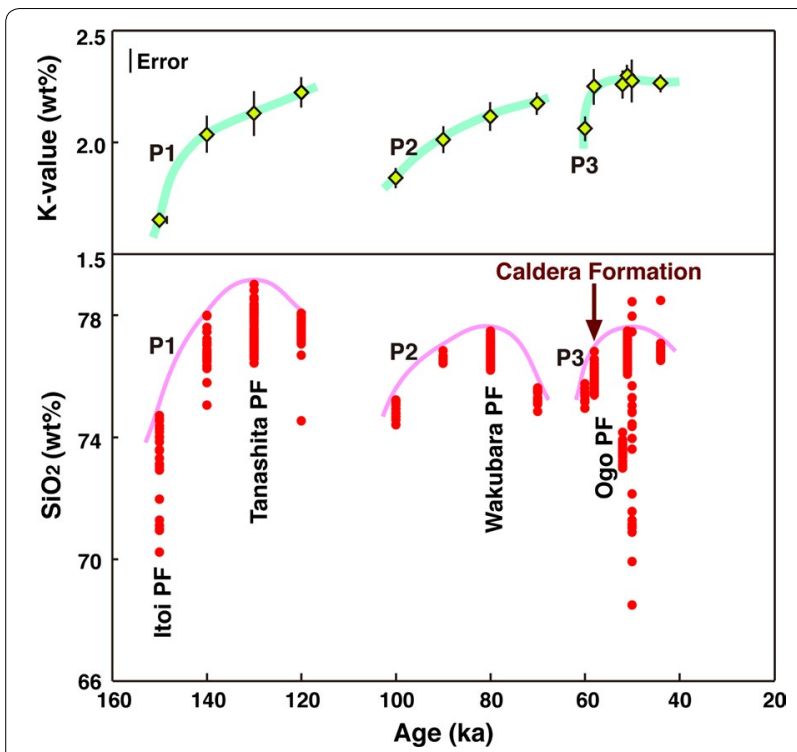

Fig. 10 Temporal variations of $\mathrm{SiO}_{2}$ (red) and K-value (green) for volcanic glass in pumice of Akagi Volcano. K-value means abundance of $\mathrm{K}_{2} \mathrm{O}$ at $\mathrm{SiO}_{2}=75.0$ wt $\%$. Observed patterns of geochemical fluctuation coincide with the sub-stages of P1, P2 and P3. The Ogo Pumice Flow eruption occurred at $60 \mathrm{ka}$ and resulted in a summit-caldera formation. Modified from Yamamoto (2016)

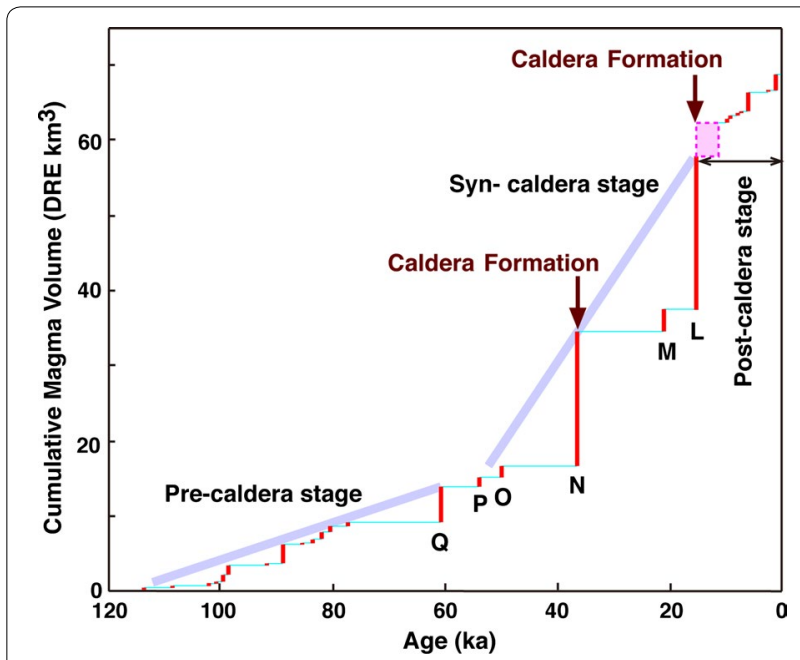

Fig. 11 Cumulative magma volume erupted from Towada Volcano. A red solid line represents an eruption event. A lilac solid line shows a tendency of the eruption rate. A pink square shows the ranges of volume and age for a volcanic edifice which is undivided into separate eruption events. $L$ to $Q$ is the name of eruption episode (Hayakawa 1985). The caldera-forming Episodes $L$ and $N$ produced the Hachinohe and Ofudo Ignimbrites, respectively. This step diagram was made from Hayakawa (1985), Nakagawa et al. (1986), Yamamoto (2015) and Kudo (unpublished data). Hayakawa (1985) defined the syn-caldera stage as the period from episode $Q$ to $L$. This paper regards the Episode $\mathrm{Q}$ as the last eruptive event in the pre-caldera stage from its geochemical feature

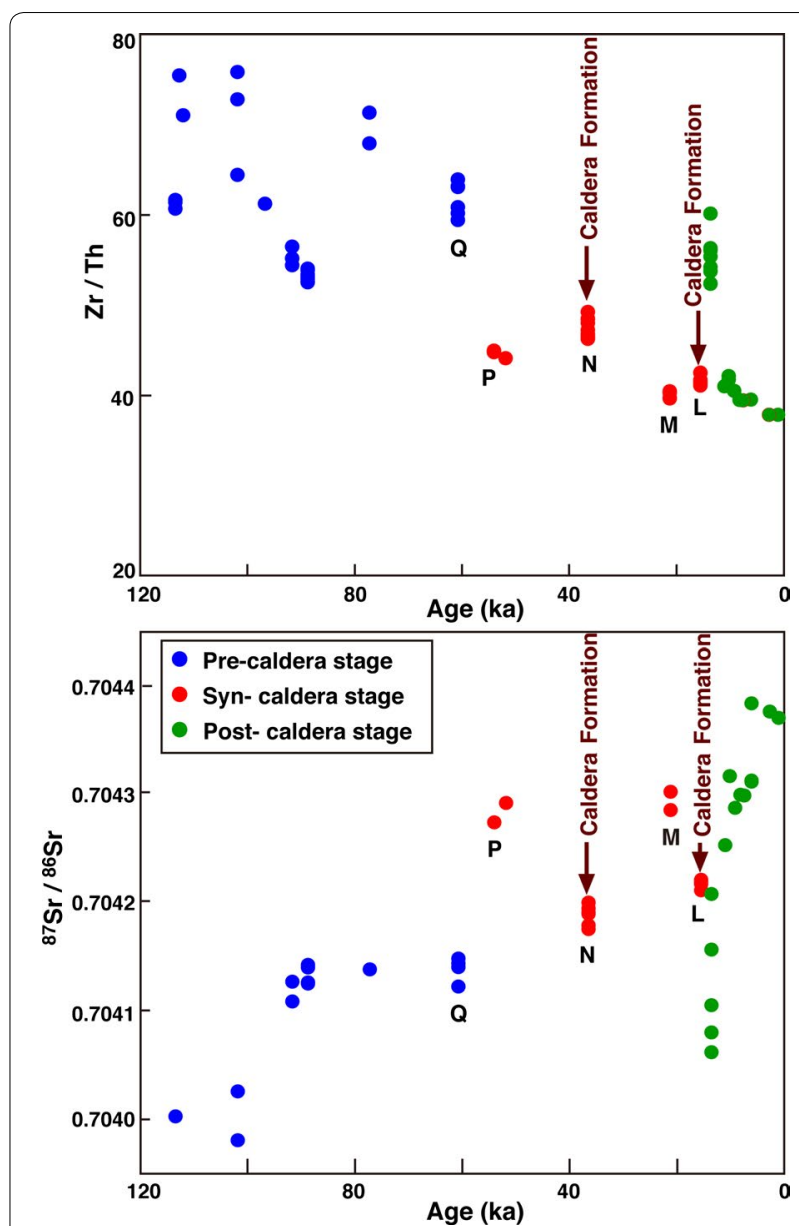

Fig. 12 Temporal variations of $\mathrm{Zr} / \mathrm{Th}$ and ${ }^{87} \mathrm{Sr} /{ }^{86} \mathrm{Sr}$ in the products of Towada Volcano. Data are from this study (Additional file 1: Appendix 1) and Hunter and Blake (1995)

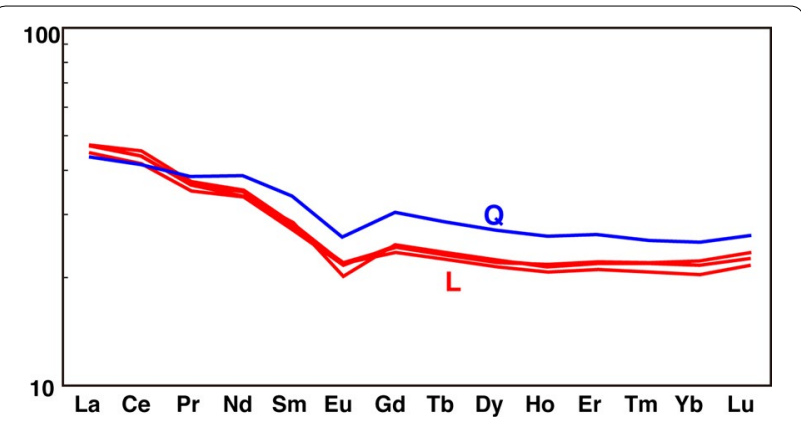

Fig. 13 Chondrite-normalized REE patterns for pumices in the Episodes $\mathrm{L}$ (Hachinohe Ignimbrite; $\mathrm{SiO}_{2}=66.6-71.8 \mathrm{wt} \%$ ) and Q (Ofudo Ignimbrite; $\mathrm{SiO}_{2}=62.2-67.8 \mathrm{wt} \%$ ) of Towada Volcano. Data are from this study (Additional file 1: Appendix 1)

\section{Decreasing case 3: Adatara Volcano}

Adatara is a large composite volcano on the volcanic front of the Northeast Japan arc (Fig. 1). Most eruptive 


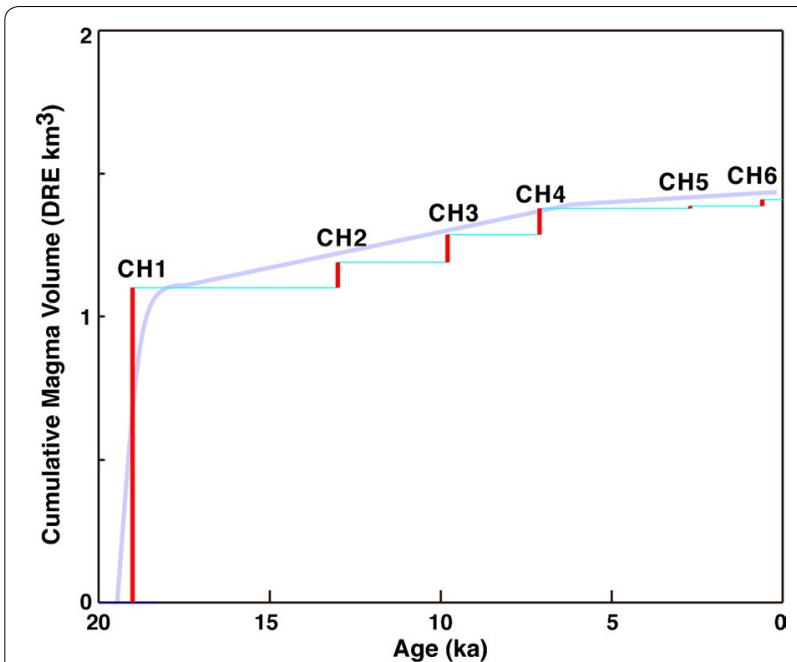

Fig. 14 Cumulative magma volume erupted from Nasu-Chausudake Volcano. A red solid line represents an eruption event. A lilac solid line shows a tendency of the eruption rate. $\mathrm{CH} 1=$ Osawa unit; $\mathrm{CH} 2=$ Yumoto unit; $\mathrm{CH} 3=$ Yahata unit; $\mathrm{CH} 4=$ Omaru unit; $\mathrm{CH} 5=$ Minenochaya unit; $\mathrm{CH} 6=1408-1410$ unit (Yamamoto 1997)

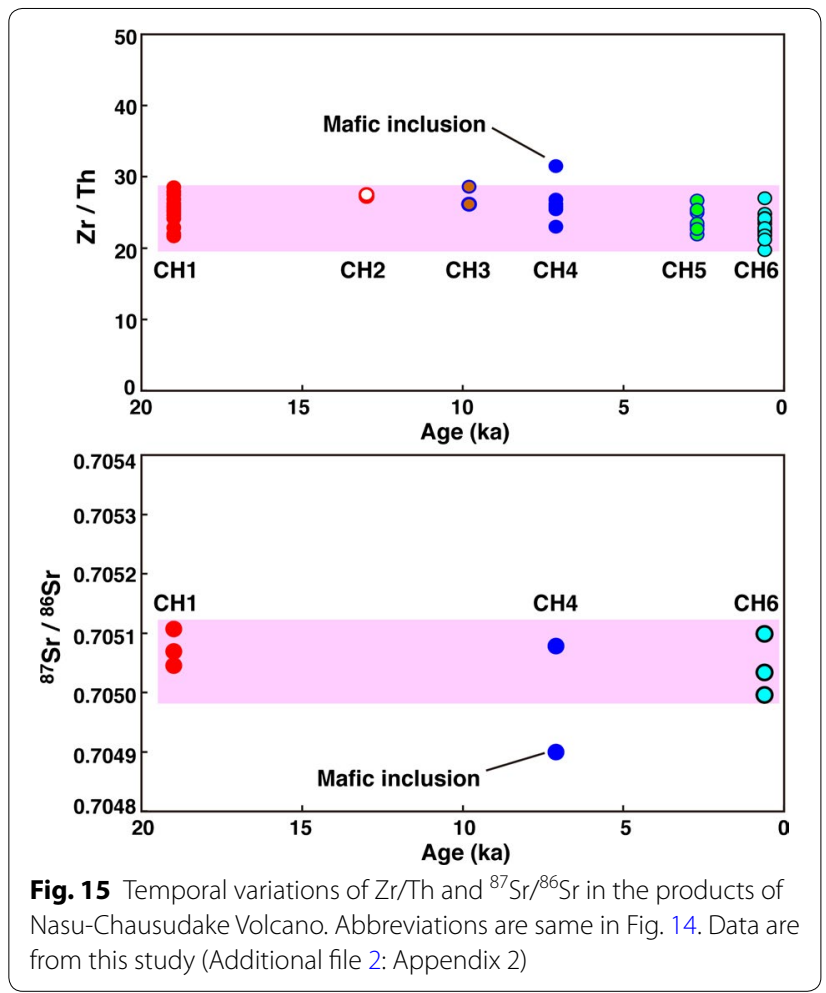

products are medium- $\mathrm{K}$ basaltic andesite to andesite (Fujinawa 1991). The young stage of activity began at $120 \mathrm{ka}$ (after a long repose of ca. 80,000 years) with the eruption of the Dake tephra, which produced Plinian

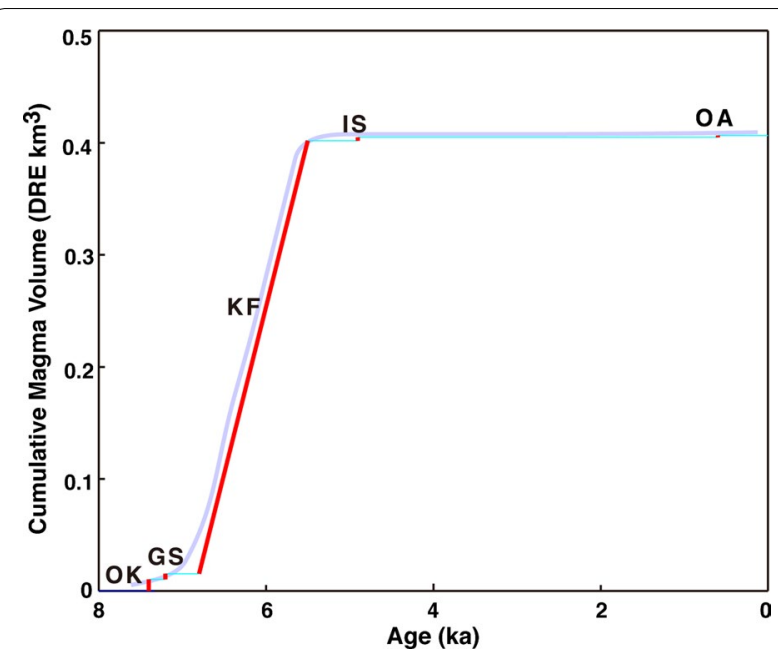

Fig. 16 Cumulative magma volume erupted from Azuma-Jododaira Volcano. A red solid line represents an eruption event. A lilac solid line shows a tendency of the eruption rate. $\mathrm{OK}=$ Okenuma unit; $\mathrm{GS}=$ Goshikinuma unit; KF = Kofuji unit; IS = Issaikyo unit; OA = Oana unit (Yamamoto 2005)

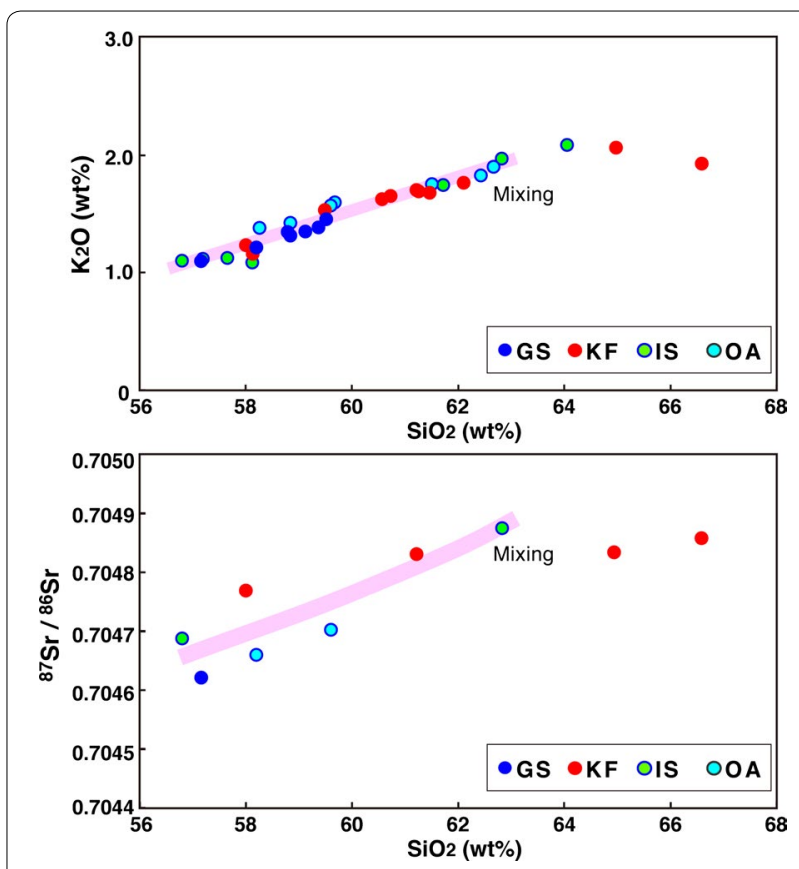

Fig. $17 \mathrm{~K}_{2} \mathrm{O}$ vs. $\mathrm{SiO}_{2}$ and ${ }^{87} \mathrm{Sr} /{ }^{86} \mathrm{Sr}$ vs. $\mathrm{SiO}_{2}$ diagrams for the products of Azuma-Jododaira Volcano. Abbreviations are same in Fig. 16. Data are from Yamamoto (2005) and this study (Additional file 3: Appendix 3)

fall and pyroclastic flow deposits totaling $1.8 \mathrm{~km}^{3}$ DRE (Fig. 18; Yamamoto and Sakaguchi 2000). After earlier eruptions of high-silica andesites $\left(60.5-62.7 \mathrm{wt} \% \mathrm{SiO}_{2}\right)$, the Dake and later eruptions produced intermediatesilica andesites (57.4-59.0 wt\% $\mathrm{SiO}_{2}$ ), reflecting renewal 


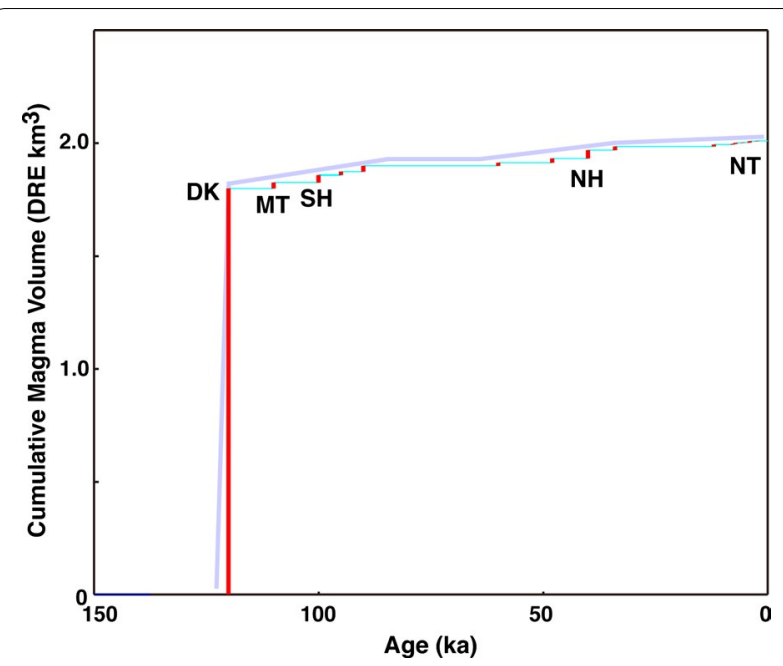

Fig. 18 Cumulative magma volume erupted from Adatara Volcano. A red solid line represents an eruption event. A lilac solid line shows a tendency of the eruption rate. DK=Dake tephra; MT=Matsukawa tephra; $\mathrm{SH}=$ Sahara tephra; $\mathrm{NH}=$ Nihonmatsu tephra; NT=Numanotaira tephra group (Yamamoto and Sakaguchi 2000)

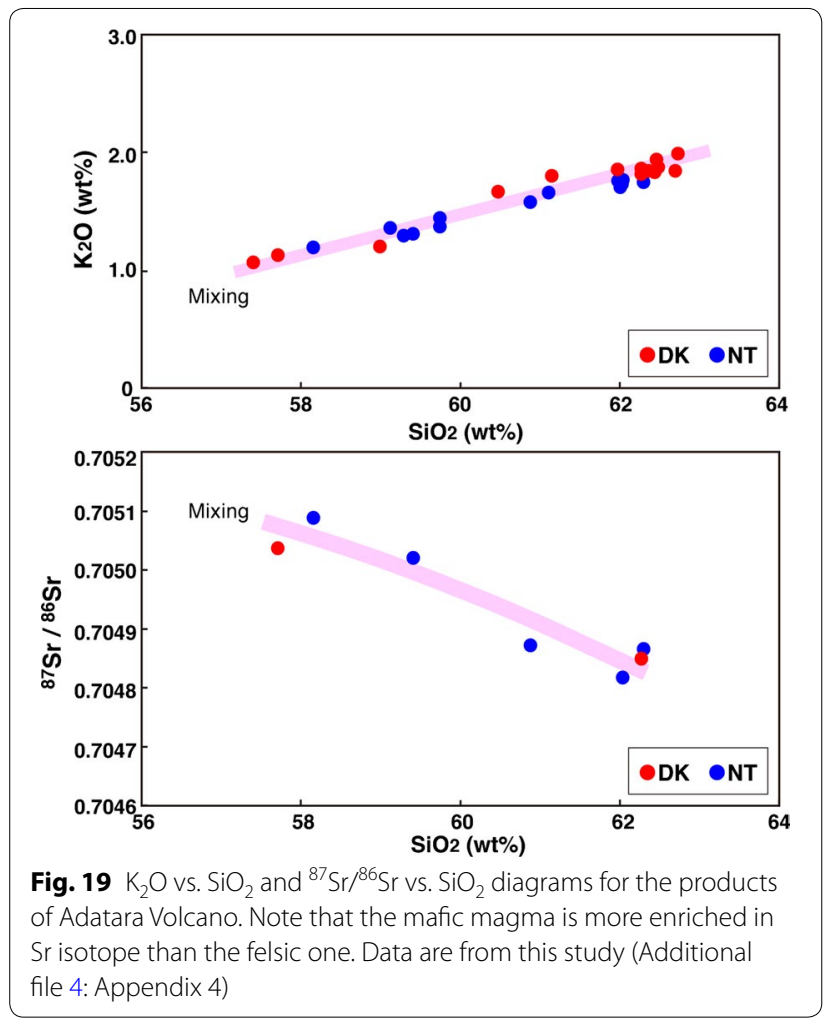

of the magma-plumbing system (Fujinawa and Kamata 2005). After the largest Dake eruption, sub-Plinian or Vulcanian eruptions produced pyroclastic units of $10^{-2}-10^{-1} \mathrm{~km}^{3}$ DRE every $10,000-20,000$ years. Since
$10 \mathrm{ka}$, six Vulcanian eruptions, producing pyroclastic units of $10^{-3}-10^{-2} \mathrm{~km}^{3}$ DRE (Numanotaira tephra group), occurred at intervals of 500-2000 years, recording a decreasing eruption rate since the Dake eruption (Fig. 18). Most ejecta of the Numanotaira tephra group comprise mingled andesite and dacite magmas showing the same linear compositional trends as the mafic and felsic magmas of the Dake eruption; the ${ }^{87} \mathrm{Sr} /{ }^{86} \mathrm{Sr}$ ratios of both end members are also almost the same as those of the Dake tephra (Fig. 19). Although there are no geochemical data on ejecta erupted between the Dake and Numanotaira tephra group due to heavy weathering, their petrographic features are similar to the Dake tephra (Yamamoto and Sakaguchi 2000). The decreasing eruption rate at Adatara is marked after the largest eruption, and the magma-plumbing system has established a longterm stability.

\section{Discussion}

Step diagrams of cumulative eruption volume versus time are useful tools for evaluating magma-discharge rates. Koyama and Yoshida (1994) classified step diagrams into four types: time-predictable, volume-predictable, strictly periodic, and non-predictable. Time- and volume-predictable cases, characterized by constant eruption rates, have been reported for active basaltic volcanoes with high eruption frequency such as Izu-Oshima (Nakamura 1964; Koyama and Hayakawa 1996), Kilauea and Mauna Loa (King 1989), and Etna (Wadge and Guest 1981; Hughes et al. 1990). In such cases, a uniform magma supply is maintained over a significant duration. However, the eruption rates of most Japanese arc volcanoes have fluctuated over their eruptive histories (Fig. 2). Thus, their eruption rates are sufficiently variable to preclude simple extrapolation from their eruptive histories. Such eruption rate fluctuations are significant for hazards evaluation since it is necessary to forecast changes to the eruption rate. It is thus necessary to understand how magmatic processes differ between volcanoes with increasing and decreasing eruption rates.

Several temporal correlations of eruption rate and magmatic evolution suggest that there exists some connection between them. Most notably, in many cases, the magma supply rate increased in response to changing magma dynamics. At Sakurajima, increased mafic magma supply during the Younger Minamidake stage is directly linked to the increased eruption rate (Figs. 3, 4). At Numazawa, Akagi, and Towada, increased crustal melting, caused by repeated intrusions of mafic magma, resulted in an increased eruption rate (and caldera formation); REE patterns in felsic magmas from these volcanoes (Figs. 7, 9, 13) suggest amphibole fractionation during crustal melting. This is consistent with the amphibolite or hornblende 
gabbro lower crust of northeast Honshu inferred by laboratory measurements of P-wave velocity and the seismic velocity structure (Nishimoto et al. 2005). Depletion of middle and heavy REEs in felsic magmas is common in island arc settings (Bachmann and Bergantz 2008) and suggests water-saturated melting of amphibolite in the lower crust (Beard and Lofgren 1991). Although amphibolite-sourced felsic magmas characterize volcanism in northeast Japan, different sources are dominant in other arcs; upper continental crust-like granitoids are the most plausible sources of the caldera-forming felsic magmas in Kyushu, including the Ito pyroclastic flow from Aira caldera (Kimura et al. 2015). Furthermore, Daisen volcano in southwest Japan (Fig. 1) produces slab-derived felsic (adakitic) products having peculiar geochemical features (Kimura et al. 2014). Eruption rates seem to reflect the complex interplay of magmatic processes at each volcano. It is therefore necessary to examine the different systems individually to understand geochemical changes with eruption rate increase.

Cases of decreasing eruption rates occur after periods of intense activity. At Nasu, Azuma, and Adatara, the largest eruptions were either the initial eruptions or those occurring after an extended period of repose, and subsequent erupted volumes decreased drastically (Figs. 14, 16, 18). In general, eruptions occur when an overpressure in the magma chamber reaches the fracture criterion of the chamber wall (Tait et al. 1989), except for huge magma chamber (Gregg et al. 2013; de Silva and Gregg 2014). After the establishment of a new eruptive conduit, the overpressure necessary for eruption becomes smaller for subsequent eruptions; major decreases in eruption volume are likely related to the lowered failure criterion. Despite repeated subsequent eruptions, the eruption rate decreased gradually in these cases (Figs. 14, 16, 18). Common to all cases of decreasing eruption rate is a well-established magma-plumbing system (stable for $10^{3}-10^{5}$ years) that does not show significant compositional variations (Figs. 15, 17, 19). In the case of constant eruption rate volcanoes (Izu-Oshima and Miyakejima), magma compositions differed over 10-100 year intervals (Nakano and Yamamoto 1991; Amma-Miyasaka and Nakagawa 2003). We speculate that these high eruption rates are probably maintained by frequent replenishment by variably differentiated magmas from a parental source. Furthermore, magma recharge may also have sustained eruption rates at Nasu, Azuma, and Adatara, although the injection frequency and volume were probably too small to replace the initial magma chamber. As a result, the long-lived magma-plumbing system was preserved without any major changes to the erupted magma compositions.

\section{Conclusion}

We examined volumetric magma eruption rates compiled from 29 datasets of well-documented Japanese Quaternary volcanoes over the past $10^{1}-10^{5}$ years. Average eruption rates are very different at each volcano and tend to change with evolving compositional or magma genesis parameters. Therefore, it is important to determine likely changes in eruption rate for long-term evaluation. Several temporal co-variations of eruption rate and magmatic evolution suggest that there are connections between them. Notably, magma supply rates at some volcanoes increased in response to changing magmageneration processes, including new/renewed supply of voluminous mafic magma batches and crustal melting. On the other hand, the long-term stability of a plumbing system (characterized by little change in erupted magma compositions) relates to decreasing eruption rates. However, the examination in this report is not sufficiently quantitative to determine evaluation criteria for volcanic risk assessments, and further work is necessary to quantify the geochemical evolution of the various magma systems reported herein.

\section{Additional files}

Additional file 1: Appendix 1. Geochemical data for Towada Volcano. Additional file 2: Appendix 2. Geochemical data for Nasu Volcano. Additional file 3: Appendix 3. Geochemical data for Azuma Volcano. Additional file 4: Appendix 4. Geochemical data for Adatara Volcano.

\section{Authors' contributions}

TY examined the volumetric magma eruption rates and drafted the manuscript. TK and Ol carried out the geochemical analysis of Towada products. All authors read and approved the final manuscript.

\section{Acknowledgements}

We thank Setsuya Nakada, Toshiaki Hasenaka, Hiroshi Shimizu and Haruo Yamasaki for discussions relevant to this study. Special thanks are given to Nguyen Hoang for isotope analysis. Instructive discussions and detailed comments by Shan de Silva and unknown reviewer significantly improve this paper. This study was supported by the Secretariat of the Nuclear Regulation Authority, Japan.

\section{Competing interests \\ The authors declare that they have no competing interests.}

Ethics approval and consent to participate

Not applicable.

\section{Publisher's Note}

Springer Nature remains neutral with regard to jurisdictional claims in published maps and institutional affiliations.

Received: 6 September 2017 Accepted: 19 April 2018

Published online: 26 April 2018 


\section{References}

Amma-Miyasaka M, Nakagawa M (2003) Evolution of deeper basaltic and shallower andesitic magmas during the AD 1469-1983 eruptions of MiyakeJima Volcano, Izu-Mariana Arc: inferences from temporal variations of mineral compositions in crystal-clots. J Petrol 44:2113-2138

Annen C, Blundy JD, Sparks RSJ (2006) The genesis of intermediate and silicic magmas in deep crustal hot zones. J Petrol 47:505-539. https://doi. org/10.1093/petrology/egi084

Aramaki S (1984) Formation of the Aira Caldera, southern Kyushu, $\sim 22,000$ years ago. J Geophys Res 89:8485-8501

Bachmann O, Bergantz GW (2008) Rhyolites and their source mushes across tectonic settings. J Petrol 49:2277-2285. https://doi.org/10.1093/ petrology/egn068

Ban M, Yamamoto T (2002) Petrological study of Nasu-Chausudake Volcano (ca. 16 ka to Present), northeastern Japan. Bull Volcanol 64:100-116

Beard JS, Lofgren GE (1991) Dehydration melting and water-saturated melting of basaltic and andesitic greenstones and amphibolites at 1.3 and $6.9 \mathrm{~kb}$. J Petrol 32:365-401

Christiansen RL (1984) Yellowstone magmatic evolution: its bearing on understanding large-volume explosive volcanism. In: Explosive volcanism: inception, evolution, and hazard. National Academy Press, Washington, pp 84-95

Crisp JA (1984) Rates of magma emplacement and volcanic output. J Volcanol Geotherm Res 20:177-211

Davidson J, de Silva S (2000) Composite volcanoes. In: Sigurdsson H, Hughton BF, McNutt SR (eds) Encyclopedia of volcanoes. Academic Press, London, pp 663-681

de Silva SL, Gregg PM (2014) Thermomechanical feedbacks in magmatic systems: implications for growth, longevity, and evolution of large calderaforming magma reservoirs and their supereruptions. J Volcanol Geotherm Res 282:77-91. https://doi.org/10.1016/j.jvolgeores.2014.06.001

Fujinawa A (1991) Tholeiitic and calc-alkaline magma series at Adatara volcano, Northeast Japan: evolution mechanisms and genetic relationship. Bull Volcanol Soc Jpn 36:241-254 (in Japanese with English abstract)

Fujinawa A, Kamata M (2005) Development history and changes of magma plumbing systems of Adatara volcano during recent 250000 years. Jpn Mag Mineral Petrol Sci 34:35-58 (in Japanese with English abstract)

Gregg PM, de Silva SL, Grosfils EB (2013) Thermomechanics of shallow magma chamber pressurization: implications for the assessment of ground deformation data at active volcanoes. Earth Planet Sci Lett 384:100-108. https://doi.org/10.1016/j.epsl.2013.09.040

Hayakawa Y (1985) Pyroclastic geology of Towada volcano. Bull Earthq Res Inst Univ Tokyo 60:507-592

Hora JM, Singer BS, Wörner G (2007) Volcano evolution and eruptive flux on the thick crust of the Andean Central Volcanic Zone: ${ }^{40} \mathrm{Ar} /{ }^{39} \mathrm{Ar}$ constraints from Volcan Parinacota, Chile. Geol Soc Am Bull 119:343-362. https://doi. org/10.1130/B25954.1

Houghton BF, Wilson CJN, McWilliams MO, Lanphere MA, Weaver SD, Briggs RM, Pringle MS (1995) Chronology and dynamics of a large silicic magmatic system: central Taupo Volcanic Zone, New Zealand. Geology 23:13-16

Hughes JW, Guest JE, Duncan AM (1990) Changing styles of effusive eruption on Mount Etna since AD 1600. In: Ryan MP (ed) Magma transport and storage. Wiley, New York, pp 385-406

Hunter AG, Blake S (1995) Petrogenetic evolution of a transitional tholeiiticcalc-alkaline series: Towada volcano, Japan. J Petrol 36:1579-1605

Kimura J-I, Gill JB, Kunikiyo T, Osaka I, Shimoshioiri Y, Katakuse M, Kakubuchi S, Nagao T, Furuyama K, Kamei A, Kawabata H, Nakajima J, van Keken PE, Stern RJ (2014) Diverse magmatic effects of subducting a hot slab in SW Japan: results from forward modeling. Geochem Geophys Geosyst 15:691-739. https://doi.org/10.1002/2013GC005132

Kimura J-I, Nagahashi Y, Satoguchi Y, Chang Q (2015) Origins of felsic magmas in Japanese subduction zone: geochemical characterizations of tephra from caldera-forming eruptions < 5 Ma. Geochem Geophys Geosyst 16:2147-2174. https://doi.org/10.1002/2015GC005854

King C (1989) Volume predictability of historical eruptions at Kilauea and Mauna Loa volcanoes. J Volcanol Geotherm Res 38:281-285

Klemetti EW, Grunder AL (2007) Volcanic evolution of Volcán Aucanquilcha: a long-lived dacite volcano in the Central Andes of northern Chile. Bull Volcanol 70:633-650. https://doi.org/10.1007/s00445-007-0158-x
Kobayashi K, Nakamura E (2001) Geochemical evolution of Akagi Volcano, NE Japan: implications for interaction between island-arc magma and lower crust, and generation of isotopically various magmas. J Petrol 42:2303-2331

Kobayashi T, Miki D, Sasaki H, Iguchi M, Yamamoto T, Uto K (2013) Geological map of Sakurajima volcano, 2nd edn. Geol Surv Jpn, AIST (in Japanese with English abstract)

Koyama M (2015) Insufficient guideline and reviews on the volcanic risks to the Japanese nuclear power plant. Kagaku 85:182-193 (in Japanese)

Koyama M, Hayakawa Y (1996) Syn- and post-caldera eruptive history of Izu Oshima Volcano based on tephra and loess stratigraphy. J Tokyo Geogr Soc 105:133-162 (in Japanese with English abstract)

Koyama M, Yoshida H (1994) Relationship between eruptive history and crustal stress field based on cumulative changes in magma discharge from volcanoes. Bull Volcanol Soc Jpn 39:177-190 (in Japanese with English abstract)

McDonough WF, Sun S-S (1995) The composition of the Earth. Chem Geol 120:223-253

Moriya I (1970) History of Akagi volcano. Bull Volcanol Soc Jpn 15:120-131 (in Japanese with English abstract)

Nakagawa H, Matsuyama C, Oike S (1986) Distribution and property of volcanic ejecta from Towada volcano. Tohoku Regional Agricultural Administration Office, $48 \mathrm{p}$ (in Japanese)

Nakamura K (1964) Volcano-Stratigraphic Study of Oshima Volcano, Izu. Bull Earthq Res Inst Univ Tokyo 42:649-728

Nakano S, Yamamoto T (1991) Chemical variations of magmas at IzU-Oshima volcano, Japan: plagioclase-controlled and differentiated magmas. Bull Volcanol 53:112-120

Nishimoto S, Ishikawa M, Arima M, Yoshida T (2005) Laboratory measurement of P-wave velocity in crustal and upper mantle xenoliths from Ichino-megata, NE Japan: ultrabasic hydrous lower crust beneath the NE Honshu arc. Tectonophysics 396:245-259

Salisbury MJ, Jicha BR, de Silva SL, Singer BS, Jimenez NC, Ort MH (2011) ${ }^{40} \mathrm{Ar} /{ }^{39} \mathrm{Ar}$ chronostratigraphy of Altiplano-Puna volcanic complex ignimbrites reveals the development of a major magmatic province. Geol Soc Am Bull 123:821-840. https://doi.org/10.1130/B30280.1

Shaw HR (1985) Links between magma-tectonic rate balances, plutonism, and volcanism. J Geophys Res 90:11275-11288

Spera FJ, Yuen DA, Kirschvink SJ (1982) Thermal boundary layer convection in silicic magma chambers: effects of temperature-dependent rheology and implications for thermogravitational chemical fractionation. J Geophys Res 87:8755-8767

Tait S, Jaupart C, Vergniolle S (1989) Pressure, gas content and eruption periodicity of a shallow, crystallising magma chamber. Earth Planet Sci Lett 92:107-123

Takahashi M, Otsuka T, Kawamata H, Sako H, Yasui M, Kanamaru T, Otsuki M, Shimada J, Atsuchi T, Umezawa T, Shiroishi T, Ichiki Y, Satake S, Kobayashi T, Ishihara K, Miki D (2011) Whole-rock chemistry for eruptive products of the Sakurajima volcano and Aira caldera, southern Kyushu: summary of 583 analytical data. Proc Inst Nat Sci Nihon Univ 46:133-200 (in Japanese with English abstract)

Takahashi M, Seki S, Suzuki H, Takemoto H, Nagai M, Kanamaru T (2012) Wholerock chemistry for eruptive products of Akagi volcano, central Japan: summary of 381 analytical data. Proc Inst Nat Sci Nihon Univ 47:341-400 (in Japanese with English abstract)

Takahashi M, Otsuka T, Sako H, Kawamata H, Yasui M, Kanamaru T, Otsuki M, Kobayashi T, Ishihara K, Miki D (2013) Temporal variation for magmatic chemistry of the Sakurajima volcano and Aira caldera region, Southern Kyushu, Southwest Japan since $61 \mathrm{ka}$ and its implications for the evolution of magma chamber system. Bull Volcanol Soc Jpn 58:19-42

Tomiya A (1991) Volume of mantle diapir compatible with life span of a typical island-arc volcano. Bull Volcanol Soc Jpn 36:211-221 (in Japanese with English abstract)

Uto K, Miki D, Hoang N, Sudo M, Fukushima D, Ishihara K (2005) Temporal evolution of magma composition in Sakurajima volcano, southwest Japan. Annu Disast Prev Res Inst Kyoto Univ 48B:341-347 (in Japanese with English abstract)

Wadge $G$ (1982) Steady state volcanism: evidence from eruption histories of polygenetic volcanoes. J Geophys Res 87:4035-4049

Wadge $G$ (1984) Comparison of volcanic production rates and subduction rates in the Lesser Antilles and Central America. Geology 12:555-558 
Wadge G, Guest JE (1981) Steady-state magma discharge at Etna 1971-1981. Nature 294:253-255

White SM, Crisp JA, Spera FJ (2006) Long-term volumetric eruption rates and magma budgets. Geochem Geophys Geosyst 7:Q03010. https://doi. org/10.1029/2005gc001002

Yamamoto T (1997) Eruptive history of Nasu-Chausudake volcano, NE Japan, based on tephrostratigrahy. J Geol Soc Jpn 103:676-691 (in Japanese with English abstract)

Yamamoto T (2003) Eruptive history of Numazawa volcano, NE Japan: new study of the stratigraphy, eruption ages, and eruption volumes of the products. Bull Geol Surv Jpn 54:323-340 (in Japanese with English abstract)

Yamamoto T (2005) Eruptive history of Azuma volcano, NE Japan, during last 7,000 years: stratigraphy and magma-plumbing system of the AzumaJododaira products. J Geol Soc Jpn 111:94-110 (in Japanese with English abstract)
Yamamoto T (2007) A rhyolite to dacite sequence of volcanism directly from the heated lower crust: late Pleistocene to Holocene Numazawa volcano, NE Japan. J Volcanol Geotherm Res 167:119-133

Yamamoto T (2011) Origin of the sequential Shirakawa ignimbrite magmas from the Aizu caldera cluster, northeast Japan: evidence for renewal of magma system involving a crustal hot zone. J Volcanol Geotherm Res 204:91-106. https://doi.org/10.1016/j.jvolgeores.2011.01.009

Yamamoto T (2015) Cumulative volume step-diagrams for eruptive magmas from major Quaternary volcanoes in Japan. GSJ Open-File Report, no. 613, Geol Surv Japan, AIST (in Japanese)

Yamamoto T (2016) Magma-discharge rate and geochemical evolution during the pumice-eruption stage of Akagi Volcano, NE Japan. J Geol Soc Jpn 122:109-126 (in Japanese with English abstract)

Yamamoto T, Sakaguchi K (2000) Eruptive history of Adatara volcano, NE Japan, during last 250,000 years based on tephrostratigrahy. J Geol Soc Jpn 106:865-882 (in Japanese with English abstract)

\section{Submit your manuscript to a SpringerOpen ${ }^{\circ}$ journal and benefit from:}

- Convenient online submission

- Rigorous peer review

- Open access: articles freely available online

- High visibility within the field

- Retaining the copyright to your article

Submit your next manuscript at $\boldsymbol{\nabla}$ springeropen.com 